\title{
DESIGN FAILURE MODES AND EFFECTS ANALYSIS OF AN ELECTRIC KART
}

\author{
Manish Kumar Kar ${ }^{1}$ \\ ${ }^{1}$ Bachelor in Technology, Department Of Mechanical Engineering, College Of Engineering and Technology, Odisha, \\ India
}

\begin{abstract}
Ecokart is an all India level competition organised by (Viridescent Educational Services) in which an electric-kart is designed and fabricated by undergraduate engineering students. An electric kart is a small, four wheeled, open vehicle but unlike a go-kart which is powered by an internal combustion engine, electric kart is run by a motor which is powered by battery. Right from design considerations, the fabrication is to be done by modifying and assembling various components. DFMEA (Design Failure Mode and Effects Analysis) is branch of FMEA (Failure Mode and Effects Analysis) which is a quality management tool that identifies the critical components of a product followed by investigating different failure modes and their subsequent effects on the whole product. This paper implements DFMEA technique on an electric-kart by identifying various failure modes and their effects on the kart.RPN (Risk Priority Technique) is a famous sub tool of it which is used in this paper in order to find the components that are more susceptible to the failure and demands more attention. Preventive measures to reduce the chances of failure are also given in the paper.
\end{abstract}

Keywords: Risk Priority Number (RPN), Severity Ranking, Ecokart, Likelihood of Detection, Likelihood of occurrence.

\section{INTRODUCTION}

Karts are small, open and four wheel vehicles. Kart racing became famous in USA in late 1950s [1].Ecokart [2] is a national level competition in India that focuses on designing and fabricating a compact electric kart i.e., the source of power for the vehicle is supplied by a motor, run by the battery. The basic difference between a go-kart [3] \& electric-kart is the source of power, where a go-kart is run by an internal combustion engine, the electric kart is powered by the battery run motor. As the environment is polluted by the petrol run vehicles, there is a vital need to find alternatives and an electric kart is one of the best possible alternatives. Owing to the go-green concept of Ecokart, this competition is fast gaining its popularity. This competition involves the designing of the body of the kart in designing software. It consists designing of the frame whose various parts are lower frame side member(LFS),rear roll hoop(RRH), frontal lateral cross member(FLC), fore af bracing(FAB), side impact members(SIM), lateral diagonal bracing(LDB), under seat member(USM) [4,Fig.1],followed by the assembly of steering, braking systems, wheels and tires and the seat. The designing considerations like compactness, lightweight, durability and driver safety, load carrying capacity of chassis are kept in mind. Static and dynamic impact load testing are to be done in the designing software to make it feasible. Followed by designing, the fabrication process comes. Rectangular/circular tubes are to be used for the primary and secondary members of the frame. Generally, karts are smaller than cars so the subassemblies like braking system, steering systems, differential systems, throttle etc. are either modified or fabricated. Suspension system is generally not included in karts because of their low weights and small track widths, so instead of them shock absorbers are mounted. The electrical parts like motor, motor controller, battery, kill switch, arduino, LCD are installed finally. So the design stage is very crucial because of various dynamic problems such as manoeuvrability, braking \& steering efficiencies that depend on the design itself. So, a safe and sound design is necessary. Failure of many subassemblies can result in putting the driver's safety at stake and imperilling the vehicle. So, a proper analysis of the sources of failures and their effects are to be done.

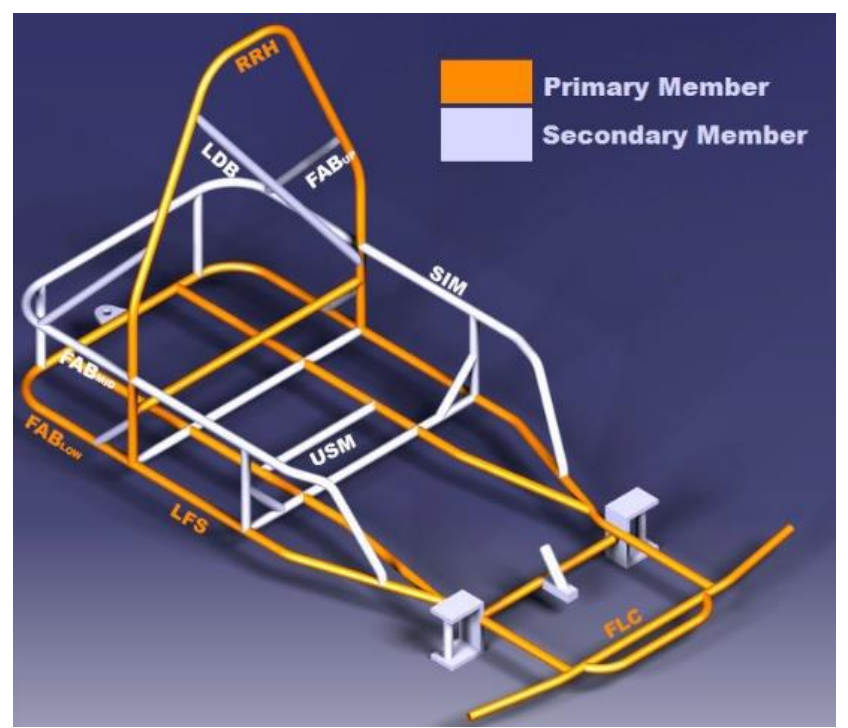

Fig. 1: frame of the kart with its various members 


\section{FAILURE MODES AND EFFECTS ANALYSIS (FMEA)}

American society of quality says that "Failure modes and effects analysis" is a step-by-step approach for identifying all possible failures in a design, a manufacturing or assembly process, or a product or service [5].Failure modes mean the ways or modes in which something might fail. Effect analysis is the analysis of consequences of failures. Failures are given priority on the basis of risk of their consequences. Therefore FMEA ensures a systematic approach and gives aid in evaluating, tracking and updating the product or the system [6].

This technique was used by contractors for the U.S. National Aeronautics and space administration (NASA) in programs like APPOLO, VIKING, VOYAGER, MAGELLAN and SKYLAB [1]. FMEA has the following types-(a)Functionalwhich is based on a functional breakdown of a system and potential failure modes are found out $\&$ general mitigations are proposed to limit the consequence of failures.(b)Designanalysis of products prior to production are to be done\& (c)Process-analysis of manufacturing assembly process are to be covered[1].

\subsection{Design Failure Modes and Effects Analysis} (DFMEA) \& Risk Priority Number (RPN)

DFMEA is a disciplined analysis of the part design with intent to correct or prevent the design based failure modes prior to first production [7]. First of all, all the components of the electric-karts are identified and its relation with other components. After that, all possible potential failure modes of the components were found out. It is followed by identifying their effect on the component \& its relative component and the vehicle as a whole. The severity rank, likelihood of occurrence rank and detection rank are given to each failure mode (1-10) based on certain criteria that are given in Table 1 , Table $2 \&$ Table 3 . The product of these three ranks will give risk priority number for the failure. It is a numeric assessment of risk assigned to a failure mode.

$\mathbf{R P N}=$ severity ranking*likelihood of occurrence*likelihood
of detection.

Then, a graph of risk priority number for each point is plotted starting from highest RPN to lowest one in descending order. This graph helps to identify the part on which we have to focus more while designing.

\subsection{Severity Ranking, Likelihood of Detection,}

\section{Likelihood of occurrence}

Severity shows the consequences a failure method. It considers the worst potential consequence of a failure of the kart. It is rated between 1 i.e., no effect to 10 i.e. extreme hazardous. Severity ranking with its description and effect is analysed in Table 1 .

Likelihood of detection shows how likely the control will detect the failure mode. Similarly, it is rated from 1 i.e. almost certain to 10 i.e. absolute uncertainty. The likelihood of detection along with its description and rating is analysed in table 3 .

Likelihood of occurrence shows the chances of various failures occurring in the components of the kart. The rating is done from 1 i.e. failure is unlikely to 10 i.e. persistent failures. Likelihood of occurrence along with its rank and possible failure rates are analysed in Table 2.

Table 1: severity effects with its rating and description

\begin{tabular}{|c|c|c|c|}
\hline $\begin{array}{l}\text { SL. } \\
\text { NO. }\end{array}$ & $\begin{array}{l}\text { SEVERITY } \\
\text { EFFECT }\end{array}$ & SEVERITY DESCRIPTION & $\begin{array}{l}\text { SEVERITY } \\
\text { RANK }\end{array}$ \\
\hline 1 & $\begin{array}{l}\text { Extreme hazardous } \\
\text { (without warning) }\end{array}$ & $\begin{array}{l}\text { The concerned failure mode affects safe operation and/or involves non- } \\
\text { compliance with government regulation without warning. Chances of } \\
\text { jeopardising the vehicle are extreme along with compromise of driver's } \\
\text { safety. }\end{array}$ & 10 \\
\hline 2 & $\begin{array}{l}\text { Hazardous (with } \\
\text { warning) }\end{array}$ & $\begin{array}{l}\text { Failure mode hinders safe vehicle operation and/or involves non-compliance } \\
\text { with government regulation with warning. Kart is inoperable and driver's } \\
\text { safety is at stake. Instant repairing not possible. }\end{array}$ & 9 \\
\hline 3 & Very high & $\begin{array}{l}\text { Kart is inoperable with loss of primary functions. Faults are detected easily } \\
\text { but instant repairing not possible. }\end{array}$ & 8 \\
\hline 4 & high & $\begin{array}{l}\text { Kart is operable but performance level of the kart is extremely low. Major } \\
\text { and necessary modifications are needed to enhance performance. }\end{array}$ & 7 \\
\hline 5 & Moderate & Vehicle is operable but convenience options don't work smoothly. & 6 \\
\hline 6 & Low & Principle operations work but performance level is reduced. & 5 \\
\hline
\end{tabular}




\begin{tabular}{|l|l|l|l|}
\hline 7 & Very low & $\begin{array}{l}\text { Concerned failure mode affects very little to the overall performance of the } \\
\text { kart. Some modifications \& repairance are needed. }\end{array}$ & 4 \\
\hline 8 & Minor & Negligible effect on kart with nominal performance level. & 3 \\
\hline 9 & Very minor & Very negligible effect on kart. Generally, no modification needed. & 2 \\
\hline 10 & None & No effect. & 1 \\
\hline
\end{tabular}

Table 2: likelihood of occurrence of the failure mode with its ranking and rating

\begin{tabular}{|l|l|l|l|}
\hline SL. NO. & PROBABILITY OF FAILURE & $\begin{array}{l}\text { POSSIBLE } \\
\text { RATES }\end{array}$ & $\begin{array}{l}\text { FAILURE } \\
\text { RANK }\end{array}$ \\
\hline 1 & $\begin{array}{l}\text { Extremely high with persistent } \\
\text { failure }\end{array}$ & 1 in 2 & 10 \\
\hline 2 & Very high, almost inevitable & 1 in 5 & 9 \\
\hline 3 & High with repeated failure & 1 in 10 & 8 \\
\hline 4 & Moderate with typical failure & 1 in 25 & 7 \\
\hline 5 & Moderate with frequent failure & 1 in 100 & 6 \\
\hline 6 & Moderate with frequent failure & 1 in 500 & 5 \\
\hline 7 & Moderate with occasional failure & 1 in 2,000 & 4 \\
\hline 8 & & & 3 \\
\hline 9 & Very low with relatively few failures & 1 in 15,000 & 2 \\
\hline 10 & Remote & 1 in 150,000 & 1 \\
\hline
\end{tabular}

Table 3: likelihood of detection of failure mode with its definition and ranking

\begin{tabular}{|c|c|c|c|}
\hline SL. NO. & $\begin{array}{l}\text { LIKELIHOOD } \\
\text { DETECTION }\end{array}$ & DEFINITION & $\begin{array}{l}\text { DETECTION } \\
\text { RANK }\end{array}$ \\
\hline 1 & Absolutely uncertainty & $\begin{array}{l}\text { Design control can't detect the major cause of } \\
\text { failure mode. }\end{array}$ & 10 \\
\hline 2 & Very remote & $\begin{array}{l}\text { Very remote chances to find the cause of failure } \\
\text { mode. }\end{array}$ & 9 \\
\hline 3 & Remote & $\begin{array}{l}\text { Remote chance that controls will detect the } \\
\text { potential cause \& then the subsequent failure } \\
\text { mode. }\end{array}$ & 8 \\
\hline 4 & Very low & $\begin{array}{l}\text { Controls have very low chance to detect the } \\
\text { potential cause/mechanism \& subsequent failure } \\
\text { mode. }\end{array}$ & 7 \\
\hline 5 & Low & Poor chance of detecting failure by controls. & 6 \\
\hline 6 & Moderate & Moderate chance of detecting failure by controls. & 5 \\
\hline 7 & Moderately high & $\begin{array}{l}\text { Moderately high chance of detecting failure by } \\
\text { controls. }\end{array}$ & 4 \\
\hline 8 & High & $\begin{array}{l}\text { Controls will detect the failure mode with little } \\
\text { deliberation. }\end{array}$ & 3 \\
\hline 9 & Very high & $\begin{array}{l}\text { Controls will detect the failure mode with almost } \\
\text { certainty. }\end{array}$ & 2 \\
\hline 10 & Certain & Detection of failure mode is certain. & 1 \\
\hline
\end{tabular}




\section{RESULTS AND DISCUSSION}

DFMEA is implemented on 17 critical components/assemblies of the kart. The detailed analysis is shown in Table 4.

Table 4: DFMEA implementation on critical components $\left(\mathrm{S}^{*}=\right.$ severity rank, $\mathrm{O} *=$ occurrence rank, Detection rank)

\begin{tabular}{|c|c|c|c|c|c|c|c|c|c|}
\hline $\begin{array}{l}\text { Sl. } \\
\text { N } \\
\text { o. }\end{array}$ & $\begin{array}{l}\text { COMP } \\
\text { ONEN } \\
\text { T }\end{array}$ & $\begin{array}{l}\text { FAILURE } \\
\text { MODE }\end{array}$ & FAILURE CAUSE & $\begin{array}{l}\text { FAILURE } \\
\text { EFFECT }\end{array}$ & $\mathbf{S}^{*}$ & O* & $\begin{array}{l}\text { D } \\
*\end{array}$ & $\begin{array}{l}\text { RPN } \\
=\mathbf{S} * \mathbf{O} \\
* \mathbf{D}\end{array}$ & $\begin{array}{l}\text { PREVENTIVE } \\
\text { MEASURES }\end{array}$ \\
\hline 1 & Frame & $\begin{array}{l}\text { Disengagement } \\
\text { and bending of } \\
\text { roll-cage members. }\end{array}$ & $\begin{array}{l}\text { Welding cracks, } \\
\text { severe vertical and } \\
\text { torsional twisting and } \\
\text { bending forces. }\end{array}$ & $\begin{array}{l}\text { Damage to roll } \\
\text { over } \\
\text { protection, } \\
\text { vibrational } \\
\text { shocks to } \\
\text { motor, failing } \\
\text { of frame, } \\
\text { driver's safety } \\
\text { is } \\
\text { compromised. }\end{array}$ & 10 & 5 & 8 & 400 & $\begin{array}{l}\text { Select the } \\
\text { material of high } \\
\text { factor of safety } \\
\text { and yield } \\
\text { strength, keep the } \\
\text { tube thickness of } \\
\text { primary members } \\
\text { bit more than } \\
\text { secondary } \\
\text { members, weld } \\
\text { properly without } \\
\text { leaving any crack. }\end{array}$ \\
\hline 2 & Bracket & $\begin{array}{l}\text { Bending } \quad \text { and } \\
\text { breakage. }\end{array}$ & $\begin{array}{l}\text { Various excessive } \\
\text { loads causing the } \\
\text { bending and bearing } \\
\text { stresses severely } \\
\text { high. }\end{array}$ & $\begin{array}{l}\text { Instability of } \\
\text { various roll- } \\
\text { cage members } \\
\text { like rear roll } \\
\text { hoop \& side } \\
\text { impact } \\
\text { members. }\end{array}$ & 9 & 4 & 8 & 288 & $\begin{array}{l}\text { Select material of } \\
\text { high factor of } \\
\text { safety, weld } \\
\text { properly without } \\
\text { residual cracks. }\end{array}$ \\
\hline 3 & Brake & $\begin{array}{l}\text { Long pedal travel, } \\
\text { poor braking, } \\
\text { brake pulling i.e. } \\
\text { kart pulls to one } \\
\text { side. }\end{array}$ & $\begin{array}{l}\text { Leaking } \\
\text { cylinder/brake pipe } \\
\text { line, air in the } \\
\text { system, low fluid } \\
\text { level in master } \\
\text { cylinder, badly } \\
\text { aligned shoes, } \\
\text { bending of brake } \\
\text { pedal. }\end{array}$ & $\begin{array}{l}\text { Inefficient } \\
\text { braking, speed } \\
\text { of the kart is } \\
\text { reduced, } \\
\text { driver's safety } \\
\text { compromised. }\end{array}$ & 8 & 6 & 8 & 384 & $\begin{array}{l}\text { Periodic } r \text { brake } \\
\text { bleeding followed } \\
\text { by keeping the } \\
\text { bleeder screw } \\
\text { tight, reline the } \\
\text { shoes properly, } \\
\text { reservoir of } \\
\text { master cylinder } \\
\text { should be always } \\
\text { filled, keep } \\
\text { pipeline leakage } \\
\text { free, select } \\
\text { standard pedal. }\end{array}$ \\
\hline 4 & $\begin{array}{l}\text { Steerin } \\
\mathrm{g} \\
\text { (consid } \\
\text { ering } \\
\text { both } \\
\text { rack \& } \\
\text { pinion } \\
\text { and } \\
\text { bell- } \\
\text { crank } \\
\text { type) } \\
\text { [8]. }\end{array}$ & $\begin{array}{lr}\text { Hard } & \text { steering, } \\
\text { looseness } & \text { in } \\
\text { steering, } & \text { car } \\
\text { wandering, } & \\
\text { shimmy } & \text { front } \\
\text { wheels, scuffed } \\
\text { tyres, steering } \\
\text { wheel jerking. }\end{array}$ & $\begin{array}{l}\text { Too tight steering } \\
\text { gear, } \\
\text { incorrect/insufficient } \\
\text { lubrication, incorrect } \\
\text { caster, camber, king- } \\
\text { pin inclination and } \\
\text { toe-in, low tyre } \\
\text { pressure, worn tie rod } \\
\text { ends, welding cracks. }\end{array}$ & $\begin{array}{l}\text { Abnormal } \\
\text { response, } \\
\text { steering } \\
\text { failure, } \\
\text { driver's safety } \\
\text { compromised. }\end{array}$ & 9 & 7 & 6 & 378 & $\begin{array}{l}\text { Proper lubrication } \\
\text { between rack and } \\
\text { pinion and at tie } \\
\text { rod ends, weld } \\
\text { properly, tie rod } \\
\text { pins should be } \\
\text { fastened correctly. }\end{array}$ \\
\hline 5 & Tires & $\begin{array}{l}\text { Side wear and } \\
\text { damaged beads, } \\
\text { puncture, } \\
\text { excessive wear in } \\
\text { the centre of tread, }\end{array}$ & $\begin{array}{l}\text { Excessive wheel } \\
\text { camber, wheel } \\
\text { misalignment, } \\
\text { under/over inflation, } \\
\text { faulty valve or }\end{array}$ & $\begin{array}{l}\text { Kart runs } \\
\text { bizarrely, } \\
\text { reduced } \\
\text { steering } \\
\text { response, }\end{array}$ & 9 & 5 & 7 & 315 & $\begin{array}{l}\text { Frequent } \\
\text { bleeding, proper } \\
\text { wheel alignment, } \\
\text { tire replacement if } \\
\text { required, choose }\end{array}$ \\
\hline
\end{tabular}




\begin{tabular}{|c|c|c|c|c|c|c|c|c|c|}
\hline & & $\begin{array}{l}\text { cuplike depression } \\
\text { on one side of } \\
\text { trade. }\end{array}$ & $\begin{array}{l}\text { leakage in tube patch, } \\
\text { loose } \\
\text { linkage, } \\
\text { debris. }\end{array}$ & $\begin{array}{l}\text { driver's safety } \\
\text { is } \\
\text { compromised, } \\
\text { and tire life is } \\
\text { decreased. }\end{array}$ & & & & & $\begin{array}{l}\text { the tire type based } \\
\text { on road } \\
\text { conditions. }\end{array}$ \\
\hline 5 & Rim & $\begin{array}{l}\text { Brittle or ductile } \\
\text { fracture, rim-out. }\end{array}$ & $\begin{array}{l}\text { Impact loads, foreign } \\
\text { transverse excessive } \\
\text { load. }\end{array}$ & $\begin{array}{l}\text { Abnormal } \\
\text { response to } \\
\text { steering, } \\
\text { damage to the } \\
\text { axles and the } \\
\text { frame, driver's } \\
\text { safety } \\
\text { compromised }\end{array}$ & 6 & 2 & $\begin{array}{l}1 \\
0\end{array}$ & 120 & $\begin{array}{l}\text { Use standard } \\
\text { rims, never put } \\
\text { unnecessary } \\
\text { transverse loads } \\
\text { on the wheel, } \\
\text { check and repair } \\
\text { the flanges in case } \\
\text { of rim-out. }\end{array}$ \\
\hline 6 & $\begin{array}{l}\text { Knuckl } \\
\mathrm{e}\end{array}$ & $\begin{array}{l}\text { Bending of the } \\
\text { steering arm, } \\
\text { structural cracks. }\end{array}$ & $\begin{array}{l}\text { Fatigue load and } \\
\text { impact load, cyclic } \\
\text { load, improper } \\
\text { mounting [9]. }\end{array}$ & $\begin{array}{l}\text { Poor response } \\
\text { to steering } \\
\text { reducing } \\
\text { operability of } \\
\text { kart, } \\
\text { malfunctionin } \\
\mathrm{g} \text { disc brake } \\
\text { callipers. }\end{array}$ & 7 & 2 & 6 & 84 & $\begin{array}{l}\text { Mount the } \\
\text { knuckle carefully; } \\
\text { choose a standard } \\
\text { knuckle \& if } \\
\text { required } \\
\text { fabrication then } \\
\text { select the material } \\
\text { of high FOS. } \\
\text { Rivet properly } \\
\text { with modified a- } \\
\text { arms, proper } \\
\text { lubrication in } \\
\text { joints. }\end{array}$ \\
\hline 7 & $\begin{array}{l}\text { Transm } \\
\text { ission }\end{array}$ & $\begin{array}{l}\text { Noise between the } \\
\text { link pins of chain } \\
\text { and sprocket, } \\
\text { breakage in chain, } \\
\text { mechanical failure } \\
\text { in differential } \\
\text { (bevel) gears. }\end{array}$ & $\begin{array}{l}\text { Insufficient } \\
\text { lubrication of gears } \\
\text { and chain-sprocket } \\
\text { drive and drive } \\
\text { shafts, improper } \\
\text { mounting, excess } \\
\text { torsion in drive shaft. }\end{array}$ & $\begin{array}{l}\text { Abnormal } \\
\text { behaviour of } \\
\text { kart, } \\
\text { operability is } \\
\text { reduced, } \\
\text { decrease in } \\
\text { speed, sudden } \\
\text { shocks due to } \\
\text { worn gear } \\
\text { teeth, sagging, } \\
\text { reduction in } \\
\text { driver's safety. }\end{array}$ & 8 & 5 & 5 & 200 & $\begin{array}{l}\text { Mount all the } \\
\text { necessary parts } \\
\text { carefully \& } \\
\text { rigidly with } \\
\text { primary members, } \\
\text { chain drive } \\
\text { arrangement } \\
\text { should not be } \\
\text { horizontal/vertical } \\
\text { completely. }\end{array}$ \\
\hline 8 & $\begin{array}{l}\text { Support } \\
\mathrm{S}\end{array}$ & $\begin{array}{l}\text { Disengagement } \\
\text { from roll-cage } \\
\text { members. }\end{array}$ & $\begin{array}{l}\text { Welding fracture at } \\
\text { the ends of the } \\
\text { support, bending. }\end{array}$ & $\begin{array}{l}\text { Instability of } \\
\text { roll-cage } \\
\text { members. }\end{array}$ & 7 & 2 & $\begin{array}{l}1 \\
0\end{array}$ & 140 & $\begin{array}{l}\text { Select the } \\
\text { material of high } \\
\text { factor of safety } \\
\begin{array}{l}\text { and } \\
\text { properly. }\end{array}\end{array}$ \\
\hline 9 & $\begin{array}{l}\text { Bumper } \\
\text { /Shock } \\
\text { Absorb } \\
\text { er }\end{array}$ & Structural failure. & $\begin{array}{l}\text { External impact load } \\
\text { exceeds the yielding } \\
\text { limit of the material. }\end{array}$ & $\begin{array}{l}\text { With failing } \\
\text { bumper further } \\
\text { impact load } \\
\text { can damage } \\
\text { FLC [4] and } \\
\text { the kart as a } \\
\text { whole. }\end{array}$ & 5 & 2 & 5 & 50 & $\begin{array}{l}\text { Choose a material } \\
\text { of high factor of } \\
\text { safety, } \\
\text { clamp/rivet } \\
\text { properly with } \\
\text { FLC. }\end{array}$ \\
\hline 10 & $\begin{array}{l}\text { Body } \\
\text { Panels }\end{array}$ & Dents or breakage. & $\begin{array}{l}\text { While fabrication } \\
\text { inappropriate mixing } \\
\text { proportion of resin } \\
\text { and hardener, } \\
\text { insufficient number } \\
\text { of fibreglass sheets to } \\
\text { be laminated for a } \\
\text { panel. }\end{array}$ & $\begin{array}{ll}\text { Loss } & \text { in } \\
\text { aesthetics. } & \end{array}$ & 4 & 3 & 6 & 72 & $\begin{array}{l}\text { Be careful while } \\
\text { mixing the resin } \\
\text { with hardener. } \\
\text { Always use } 3-5 \\
\text { glass for } \\
\text { lamination for a } \\
\text { panel. }\end{array}$ \\
\hline
\end{tabular}




\begin{tabular}{|c|c|c|c|c|c|c|c|c|c|}
\hline 11 & Motor & $\begin{array}{l}\text { Winding rupture, } \\
\text { short circuit, rotor } \\
\text { and stator faults, } \\
\text { bearing failure [9]. }\end{array}$ & $\begin{array}{l}\text { Improper installation, } \\
\text { vibrational shocks, } \\
\text { overloading, } \\
\text { presence of foreign } \\
\text { debris, erroneous } \\
\text { lubrication of drive } \\
\text { gear. }\end{array}$ & $\begin{array}{l}\text { Rpm } \\
\text { decreases, } \\
\text { abnormal } \\
\text { starting, } \\
\text { overheating } \\
\text { that can block } \\
\text { bearings and } \\
\text { damage it, } \\
\text { repair cost } \\
\text { increases }\end{array}$ & 6 & 3 & 2 & 36 & $\begin{array}{l}\text { Connections are } \\
\text { carefully done, } \\
\text { inspect motor } \\
\text { mount \&, bolts } \\
\text { and nuts, and } \\
\text { check for any } \\
\text { misalignment. }\end{array}$ \\
\hline 12 & $\begin{array}{l}\text { Motor } \\
\text { Control } \\
\text { ler }\end{array}$ & $\begin{array}{l}\text { Short circuit in any } \\
\text { component, failure } \\
\text { in any component. }\end{array}$ & $\begin{array}{l}\text { Faulty connections, } \\
\text { BIOS } \\
\text { incompatibility, } \\
\text { failure in bipolar } \\
\text { junction transistor. }\end{array}$ & $\begin{array}{l}\text { Motor doesn't } \\
\text { start Rpm } \\
\text { variations. }\end{array}$ & 5 & 2 & 2 & 20 & $\begin{array}{l}\text { Connections are } \\
\text { checked properly, } \\
\text { repair electrical } \\
\text { component if } \\
\text { required. }\end{array}$ \\
\hline 13 & Battery & $\begin{array}{lr}\text { Separator } & \text { failure, } \\
\text { short } & \text { circuit, } \\
\text { electrolyte loss, } \\
\text { electrolyte } \\
\text { stratification [10]. }\end{array}$ & $\begin{array}{l}\text { High temperature, } \\
\text { high charging rates, } \\
\text { overcharging, } \\
\text { improper insulation } \\
\text { of wires and their } \\
\text { connections, } \\
\text { inefficient battery } \\
\text { casing. }\end{array}$ & $\begin{array}{l}\text { Reduced } \\
\text { performance } \\
\text { and in some } \\
\text { cases not } \\
\text { operable at all. }\end{array}$ & 4 & 5 & 2 & 40 & $\begin{array}{l}\text { Always check } \\
\text { wire connections } \\
\text { and their } \\
\text { insulation, battery } \\
\text { casing. Don't } \\
\text { overcharge. }\end{array}$ \\
\hline 14 & $\begin{array}{l}\text { Throttle } \\
\text { Pedal }\end{array}$ & $\begin{array}{l}\text { Disengagement } \\
\text { from fore aft } \\
\text { bracing (low), } \\
\text { signal sent by } \\
\text { throttle pedal to } \\
\text { motor is hindered. }\end{array}$ & $\begin{array}{l}\text { Improper welding, } \\
\text { excessive pedal effort } \\
\text { from drive, wiring } \\
\text { between pedal and } \\
\text { motor controller is } \\
\text { halted. }\end{array}$ & $\begin{array}{l}\text { Speed of the } \\
\text { motor shaft is } \\
\text { decreased }\end{array}$ & 4 & 3 & 2 & 24 & $\begin{array}{l}\text { Weld efficiently; } \\
\text { check the wiring } \\
\text { thoroughly with } \\
\text { proper insulation. }\end{array}$ \\
\hline 15 & $\begin{array}{l}\text { Driver } \\
\text { Seat }\end{array}$ & $\begin{array}{l}\text { Structural failure } \\
\text { in the seat frame, } \\
\text { disengagement } \\
\text { from the lower } \\
\text { frame. }\end{array}$ & $\begin{array}{l}\text { Inefficient welding of } \\
\text { the seat frame and } \\
\text { between the seat } \\
\text { frame and lower } \\
\text { frame of the kart. }\end{array}$ & $\begin{array}{l}\text { Driver's safety } \\
\text { is } \\
\text { compromised }\end{array}$ & 6 & 2 & 5 & 60 & $\begin{array}{l}\text { Choose a material } \\
\text { of high factor of } \\
\text { safety for seat } \\
\text { frame, welding } \\
\text { should be done } \\
\text { without leaving } \\
\text { any fractures. }\end{array}$ \\
\hline 16 & $\begin{array}{l}\text { Arduin } \\
\mathrm{o}\end{array}$ & $\begin{array}{l}\text { Wrong display of } \\
\text { battery life and } \\
\text { speed in the LCD. }\end{array}$ & $\begin{array}{ll}\text { Short circuit in its } \\
\text { components, wiring } \\
\text { problems, } & \text { wrong } \\
\text { program code. } & \end{array}$ & $\begin{array}{l}\text { Kart's running } \\
\text { speed is not } \\
\text { measured, } \\
\text { sudden } \\
\text { stoppage of } \\
\text { kart as battery } \\
\text { drains but } \\
\text { driver is } \\
\text { unknown to it. }\end{array}$ & 3 & 6 & 7 & 126 & $\begin{array}{l}\text { Wirings should be } \\
\text { checked and thus } \\
\text { corrected with } \\
\text { proper insulation. } \\
\text { Program code } \\
\text { should be written } \\
\text { correctly. }\end{array}$ \\
\hline 17 & $\begin{array}{l}\text { Kill } \\
\text { Switch }\end{array}$ & Electrical failure. & $\begin{array}{l}\text { Short circuit, wiring } \\
\text { problems, improper } \\
\text { insulation, } \\
\text { vibrational shocks. }\end{array}$ & $\begin{array}{l}\text { Vehicle } \\
\text { becomes } \\
\text { inoperable. }\end{array}$ & 3 & 5 & 7 & 105 & $\begin{array}{l}\text { Check wirings } \\
\text { frequently, proper } \\
\text { installation to } \\
\text { prevent shocks. }\end{array}$ \\
\hline
\end{tabular}




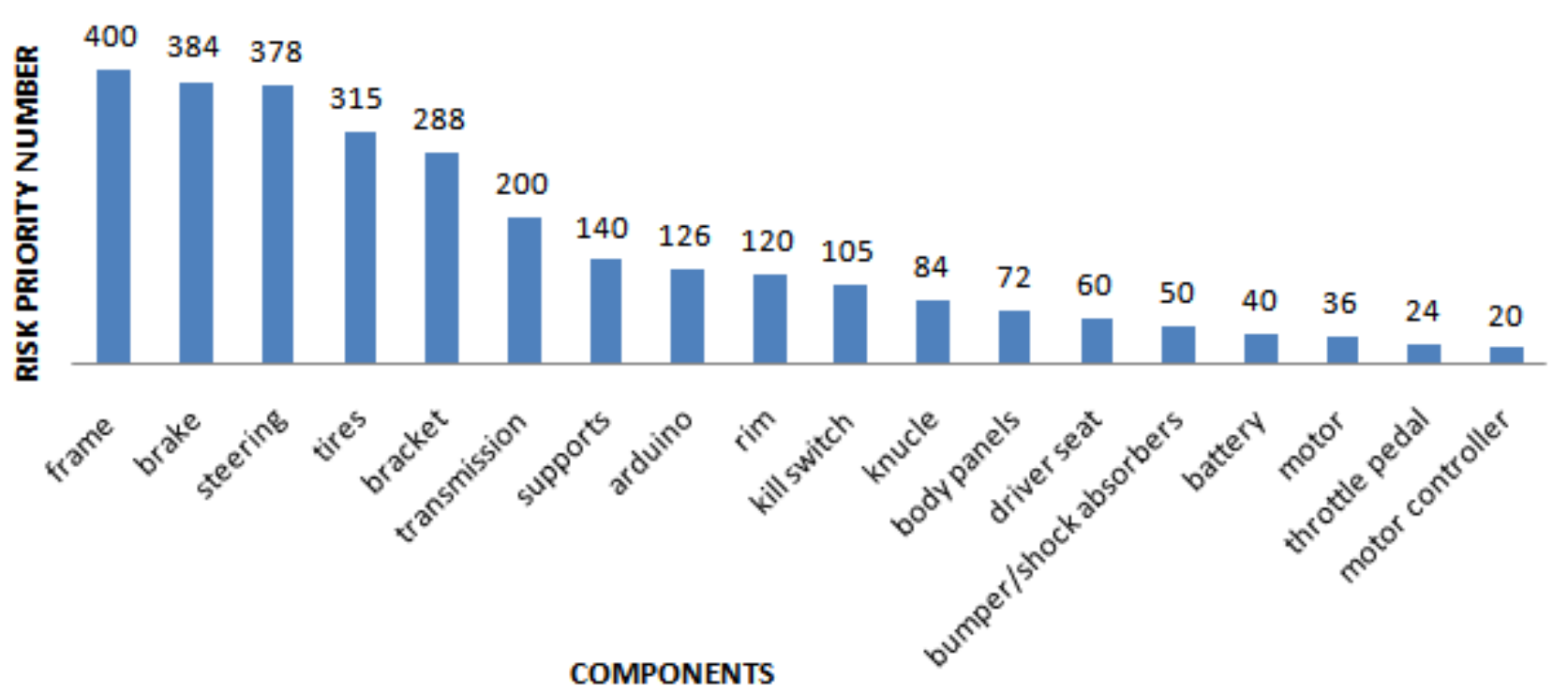

Fig 2: RPN (risk priority number) graph

Priority chart for components is prepared based on their risk priority number (Fig. 2). The components/assemblies that have higher RPN such as frame, braking system, steering assembly, tires, brackets and transmission assembly should be given more priority and attention while designing and fabrication as they are more suspected to failure. Possible preventive measures for different components regarding their failure modes are also listed out in the DFMEA implementation table to control the risks up to a certain point.

\section{CONCLUSION}

DFMEA is successfully applied to various components of an electric kart listing out all their possible failure modes and their causes. Based on the likelihood of occurrence, likelihood of detection and severity effects of the failure modes Risk Priority Number for the components was computed followed by a priority graph in which components are prioritized according to their risk priority number.

\section{REFERENCES}

[1]. Failure mode and effects analysis. https://en.wikipedia.org/wiki/Failure_mode_and_effects_ana lysis

[2]. About Ecokart. www.ecokart.in/.

[3]. Go-kart. https://en.wikipedia.org/wiki/Go-kart

[4]. Baja saeindia 2016 rulebook. http://www.bajasaeindia.org/pdf/2016_Baja\%20SAE\%20In dia\%20Rulebook.pdf, pp. 21-26

[5]. Failure Mode Effects Analysis (FMEA) ASQ.asq.org/learn-about-quality/process-analysis-

tools/.../fmea.html

[6]. Xfmea Report Sample - Design FMEA.www.reliasoft.com/pubs/xfmea_dfmea.pdf. pp. 2-3

[7]. Design FMEA (DFMEA) Tutorial. http://sixsigmatutorial.com/design-fmea-tutorial/431/
[8]. Bell Crank $\quad$ Steering System.http://www.tlracing.com/Products/Default.aspx?Pro dID=TLR231027

[9]. Fatigue and Impact Analysis of Automotive Steering Knuckle under Operating Load Cases http://www.altairatc.com/india/bangalore/technicalpresentations/RNL-04-Fatigue-and-Impact-Analysis-ofAutomotive_Dr-Mahalingam.pdf [10]. FMEA-Electrical Motor. www.slideshare.net/MohammedHamedAhmedSo/casestudy2-45748975.

\section{BIOGRAPHY}

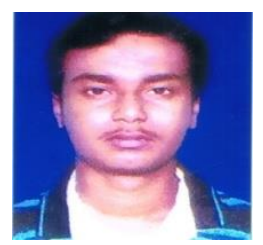

Manish Kumar Kar is a student of College of Engineering And Technology, Bhubaneswar, Odisha pursuing Bachelor in Technology in Mechanical Engineering. $\mathrm{He}$ is a member of Society Of Automotive Engineers, India.He has participated in BAJA India 2016. $\mathrm{He}$ has participated and served as head of steering department in Ecokart 2016 